\title{
A Study on School Dropouts and Student Strength of Dharwad District of Karnataka, India
}

\author{
S.V. Halawar* \\ Karnatak Arts College Dharwad, India \\ *Corresponding author:
}

A B S T R A C T

\section{Keywords}

Education, School dropouts, ANOVA, t-test

\section{Article Info}

Accepted:

15 January 2019

Available Online:

10 February 2019

\begin{abstract}
Keeping in view, the increasing importance of education in India, this study is an attempt to understand the nature of student strength and school dropouts. To realize these objectives it is collected the secondary data from district BEO office, Public Education sector (Sarvajanika Shikshana Elake), Dharwad. Results are derived by using statistical techniques such as bar diagrams, linear trend analysis, t-test and analysis of variance. The results reveals that female student strength is comparatively high in the government schools from 2011-12 to 16-17 and male strength in private schools and later during 201718 , this scenario has changed and also observed the significant difference in the school dropouts year wise.
\end{abstract}

\section{Introduction}

Education is the passport to accelerate economic growth. It is the key to build a nation. In India, under various constitutional provisions and five year plans educational facilities have been expanded at all levels. According to article 45 of the constitution of India, the state shall endeavor to provide within a period of ten years from the commencement of this constitution for free and compulsory education for all children until they complete the age of fourteen years. As per $93^{\text {rd }}$ amendment to the constitution, now elementary education has become the fundamental right of every child, but still millions of children are out of school. The top most reasons for dropping out are lack of interest in studies, economic conditions of the parents, migration of the family and to help the family in domestic work.

After dropping out, the children are involved in helping their parents in household work, field work, working to earn money, most of students are also sitting idle and doing nothing more or less the students after dropping out from upper primary classes are helping the parents in earning the money, either by getting them involved in the agriculture and allied activities or directly by doing work to earn money (Rao et al., 2004; 
Rao and Mohan, 2000; Chatterjee, 1975; Chatterjee and Madhusudan, 1998; Chitnis Suma, 1982).

In addition to the short-term nature of many studies of predictive variables (Ekstrom et al., 1986), much of the recent dropout research has been done with students from large metropolitan areas (Fine, 1986) or has focused on specific ethnic groups (Strong and Robins, 1972; Fernandez and Shu, 1988). Whether the results of these kinds of studies are applicable to students in less urban areas or to schools with a minimum percentage of minority students has not been established.

Dropout in Secondary Education: A Study of Children living in slums of Delhi (Sunita Chugh, 2011), the dropout problem is pervasive in the Indian education system. Many children, who enter school, are unable to complete secondary education and multiple factors are responsible for children dropping out of school. Risk factors begin to add up even before students enroll in school that includes: poverty, uneducated or low educational level of parents, the weak family support, pattern of schooling of sibling, and lack of pre-school experiences. Family background and domestic problems create an environment which negatively affects the value of education. Further, students could drop out as a result of a multitude of school factors such as unfriendly atmosphere, poor comprehension, absenteeism, attitude and behavior of the teachers and failure or repetition in the same class, etc. When student experience school failure, they become disturbed with lack of achievement and end up alienated and experience exclusion leading to eventual dropout. It is essential to carefully design preventive measures and intervention strategies that could be adopted in order to help all adolescent dropouts. Certain precautionary measures can be implemented throughout the target population, while others must take into account the variety of dropout profiles.

School Dropout across Indian States and Union Territories, An Econometric Study Rupon Basumatary Amguri College and Research Scholar, Gauhati University, Guwahati, Assam, INDIA stated that the Central Government is implementing several schemes in collaboration with State Governments to ensure development in the education sector. The Sarva Shiksha Abhiyan is being implemented in accordance with the norms and standards of the RTE Act to enhance enrolment and retention of children, with context- specific interventions for $\mathrm{SC} /$ ST students and a multi-pronged approach for reducing dropout rates. This includes interalia strengthening of school infrastructure and facilities, residential hostel buildings for children in habitations not covered by regular schools, provisioning for additional teachers, regular training of teachers, provision for free text books and uniforms to children. The Kasturba Gandhi Balika Vidyalaya Scheme provides for setting up of residential upper primary schools for girls from SCs, STs, OBCs and Minority communities. The Mid Day Meal Scheme is also being implemented with a view to enhance enrolment and retention of children in schools. Unlike many other countries of the world today, India is increasingly growing young as reflected in the population profile of the country. According to Census Bureau of India, $40 \%$ of population is below the age of 18 and by 2015 it is expected that $55 \%$ will be under the age of 20. With a satisfactorily large proportion of population in the very young age, it is expected that in 2020, the average Indian will be only 29 years old, compared with the average age of 37 years in China and the US, 45 in west Europe and 48 in Japan. This demographic process will create a large and growing labour force, which is expected to deliver spin-offs in terms of growth and 
prosperity through a number of routes. People of this young age group are measured to be the most productive class of human resources. Therefore, sustainability of economic development of the country will depend on how this section of people is built up and utilized.

\section{Materials and Methods}

Here it is taken the secondary data from district BEO office, Public Education sector (Sarvajanika Shikshana Elake). It includes the students' strength and dropouts of students in dharwad rural areas. We utilized the necessary data for our study. And here it is used statistical tools like trend analysis and Analysis of variance to derive results of the data.

\section{Results and Discussion}

\section{Data analysis}

From the Table 3 and Figure 3 Primary level strength it is observed that overall strength from 2010-11 to 2017-18 gradually increasing, by observing the trend lines of total primary level population, Govt. aided and Private unaided schools strength of students it is clear that how population is increasing student strength is also increasing. From the data it is observed that Government aided schools strength is twice the strength of private schools. In the government as well as private schools till 2015-16 students strength is almost constant but after that there is significant increment in the strength, it may be because of new rules in education system or techniques like Nali Kali/ Kali Nali and scholar ships like Vidyashree and so on (Fig. 2).

From Table 4 and figure 4 of Upper primary level strength it is clearly observed that, strength from 2010-11 to 2017-18 it is gradually decreasing, by observing the decreasing strength of the students we come to know that overall strength of younger population is decreasing. From the figure 4 it is observed that government school students' strength is trice the strength of private schools in upper primary level. From 2010-11 to 2015-16 student strength is almost constant after that there is sudden decrement in the strength.

\section{Gender wise primary level strength in the Government and Private Schools}

From table 5 and figure 5 Primary level gender wise strength in the Govt. schools, it is observed that except the year 2017-18 from 2010-11 to 2016-17 female strength is slightly more than male strength and another view of the graph shows that there is not much difference in the sex ratio of dharwad district. From the paired t-test is found non-significant at $5 \%$ level of significance, that show there is a no difference in strength of male and female in the government schools. If we compare figure 5 and 6 it is understood that parents view in case of giving education to their children is varying gender wise, we can clearly observe that in the Government schools female population is high where as in the private schools male population is high.

From Table 6 and figure 6 Primary level gender wise strength in the Private schools, it is observed that from 2010-11 to 2017-18 male strength is slightly more than female strength. From the paired t-test is found significant at $5 \%$ level of significance, that show there is a significant difference in strength of male and female in the private schools. This analysis shows that parents are interested to join their male child to private schools for their good opinion about private school. From the figure it is observed that from 2010-11 to till 2015-16 male as well as female student's strength in the private 
schools is slowly increasing, but for the year 16-17 and 17-18 it is decreased and from the figure-3 govt. school strength is increasing suddenly. By observing this, we come to know that govt. Education department drawing new techniques to attract students towards govt. schools and improving the education quality.

Table.1 Year wise data analysis of different areas of dharwad district

\begin{tabular}{|l|l|l|l|l|l|l|l|}
\hline Districts & $\mathbf{2 0 1 2 - 1 3}$ & $\mathbf{2 0 1 3 - 1 4}$ & $\mathbf{2 0 1 4 - 1 5}$ & $\mathbf{2 0 1 5 - 1 6}$ & $\mathbf{2 0 1 6 - 1 7}$ & $\mathbf{2 0 1 7 - 1 8}$ & $\mathbf{2 0 1 8 - 1 9}$ \\
\hline $\begin{array}{l}\text { Dharwad } \\
\text { rural }\end{array}$ & 91 & 25 & 516 & 18 & 14 & 6 & 13 \\
\hline $\begin{array}{l}\text { Dharwad } \\
\text { city }\end{array}$ & 265 & 54 & 583 & 10 & 12 & 3 & 5 \\
\hline $\begin{array}{l}\text { Hubli } \\
\text { rural }\end{array}$ & 141 & 37 & 660 & 35 & 22 & 19 & 5 \\
\hline Hubli city & 496 & 103 & 306 & 86 & 27 & 26 & 8 \\
\hline Kalgatagi & 236 & 81 & 355 & 9 & 32 & 7 & 8 \\
\hline Kundagol & 168 & 59 & 307 & 50 & 10 & 1 & 6 \\
\hline Navalgund & 123 & 55 & 430 & 20 & 4 & 15 & 12 \\
\hline
\end{tabular}

$\mathrm{H}_{0}$ : There is no significant difference in the year wise number of drop outs (OOSC).

$\mathrm{H}_{1}$ : There is a significant difference in the year wise number of drop outs (OOSC).

\begin{tabular}{|l|l|l|l|l|l|}
\hline \multicolumn{7}{|c|}{ ANOVA } \\
\hline & Sum of Squares & Df & Mean Square & F & Sig. \\
\hline Between Groups & 1155107.347 & 6 & 192517.891 & 33.688 & .000 \\
\hline Within Groups & 240017.714 & 42 & 5714.707 & & \\
\hline Total & 1395125.061 & 48 & & & \\
\hline
\end{tabular}

Table.2 Post Hoc Tests

Homogeneous Subsets

\begin{tabular}{|l|l|l|l|l|}
\hline Tukey HSD \\
\hline Factor & N & \multicolumn{3}{|l|}{ Subset for alpha $=0.05$} \\
\hline & & 1 & 2 & 3 \\
\hline $2018-19$ & 7 & 8.1429 & & \\
\hline $2017-18$ & 7 & 11.0000 & & \\
\hline $2016-17$ & 7 & 17.2857 & & \\
\hline $2015-16$ & 7 & 32.5714 & & \\
\hline $2013-14$ & 7 & 59.1429 & & \\
\hline $2012-13$ & 7 & & 217.1429 & \\
\hline $2014-15$ & 7 & & & 451.0000 \\
\hline Sig. & \multicolumn{5}{|l|}{. } & 1.000 & 1.000 \\
\hline Means for groups in homogeneous subsets are displayed. \\
\hline a. Uses Harmonic Mean Sample Size $=7.000$. \\
\hline
\end{tabular}


Fig.1 Means plots

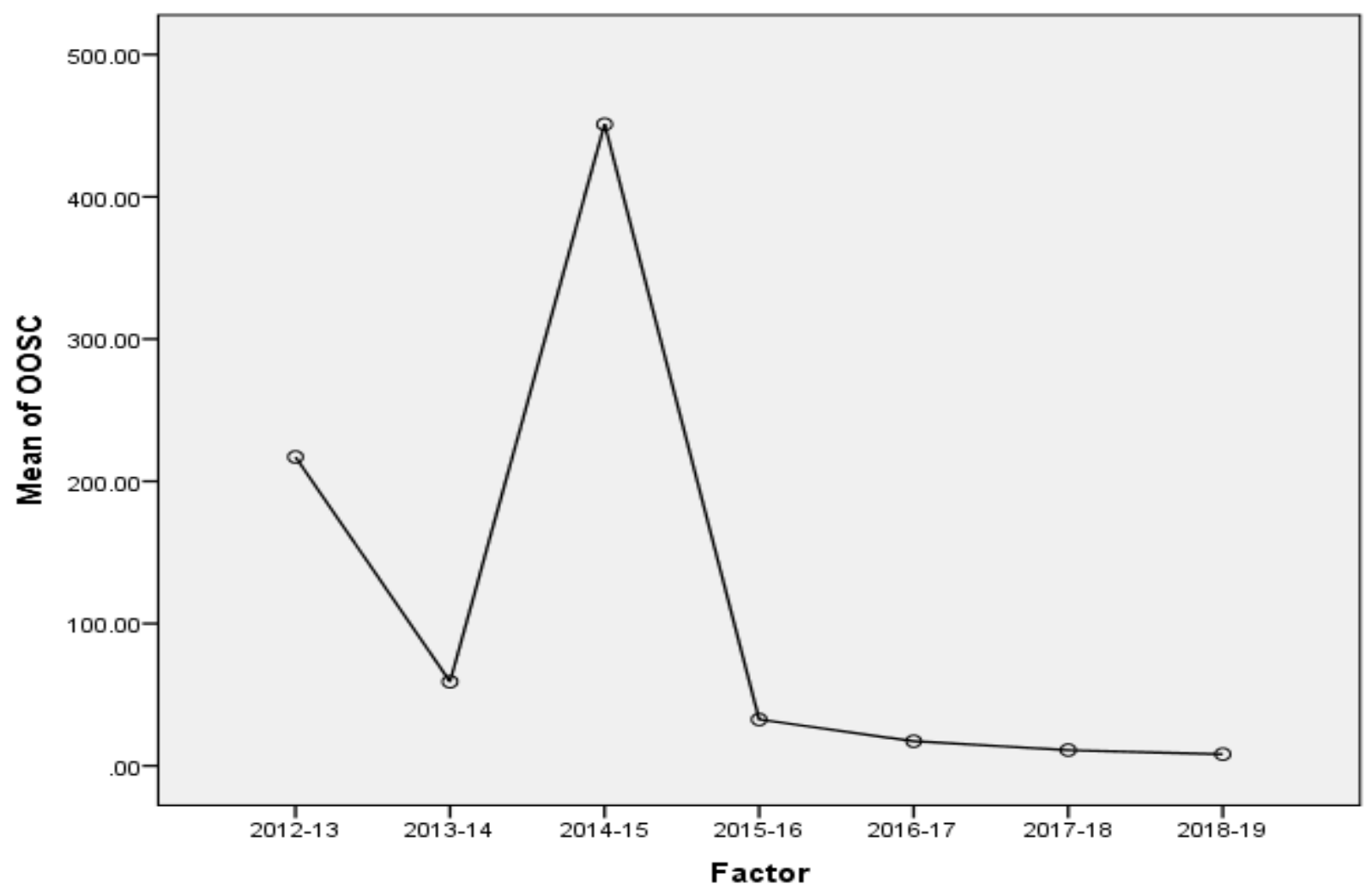

Table.3 Family Level Strength

\begin{tabular}{|l|l|l|l|}
\hline Year & Gov+Aided & Pvt+Unaided & Total \\
\hline $\mathbf{2 0 1 0 - 1 1}$ & 124661 & 52719 & 178716 \\
\hline $\mathbf{2 0 1 1 - 1 2}$ & 111286 & 58796 & 171584 \\
\hline $\mathbf{2 0 1 2 - 1 3}$ & 105043 & 53428 & 159960 \\
\hline $\mathbf{2 0 1 3 - 1 4}$ & 98473 & 53249 & 153165 \\
\hline $\mathbf{2 0 1 4 - 1 5}$ & 102387 & 61221 & 163608 \\
\hline $\mathbf{2 0 1 5 - 1 6}$ & 103293 & 62460 & 167164 \\
\hline $\mathbf{2 0 1 6 - 1 7}$ & 163562 & 74610 & 238172 \\
\hline $\mathbf{2 0 1 7}-18$ & 209949 & 98082 & 308031 \\
\hline & & & \\
\hline
\end{tabular}


Fig.2

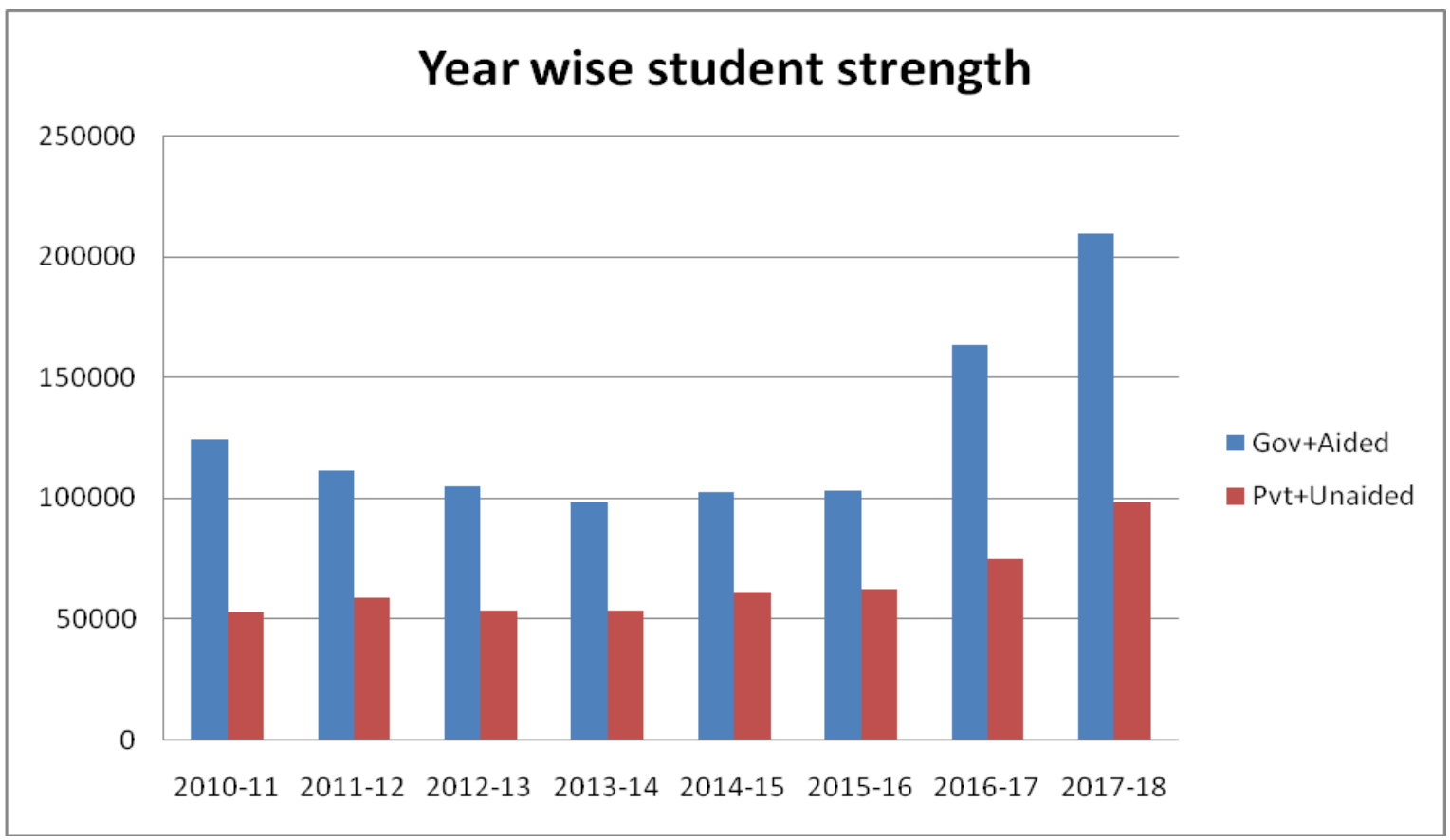

Fig.3

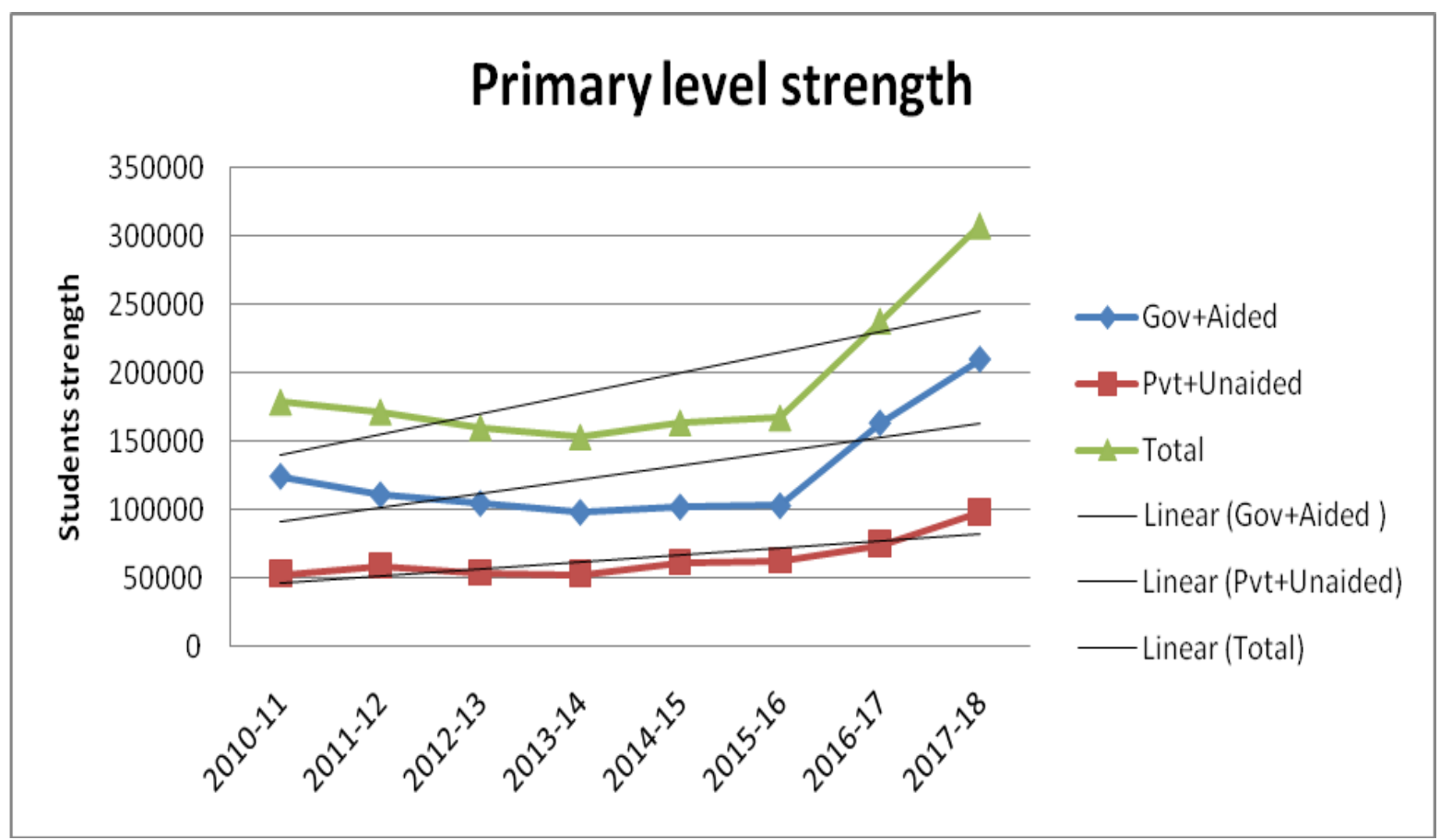


Table.4 Upper primary level strength

\begin{tabular}{|l|l|l|l|}
\hline Year & Gov+Aided & Pvt+Unaided & Total \\
\hline $\mathbf{2 0 1 0 - 1 1}$ & 78746 & 22549 & 102368 \\
\hline $\mathbf{2 0 1 1 - 1 2}$ & 75,853 & 24909 & 101865 \\
\hline $\mathbf{2 0 1 2}-13$ & 70957 & 23878 & 95940 \\
\hline $\mathbf{2 0 1 3 - 1 4}$ & 68199 & 23249 & 92511 \\
\hline $\mathbf{2 0 1 4 - 1 5}$ & 68175 & 27213 & 95388 \\
\hline $\mathbf{2 0 1 5}-16$ & 65528 & 28016 & 94159 \\
\hline $\mathbf{2 0 1 6}-17$ & 40242 & 16782 & 57024 \\
\hline $\mathbf{2 0 1 7}-18$ & 38768 & 17340 & 56108 \\
\hline
\end{tabular}

Fig.4a

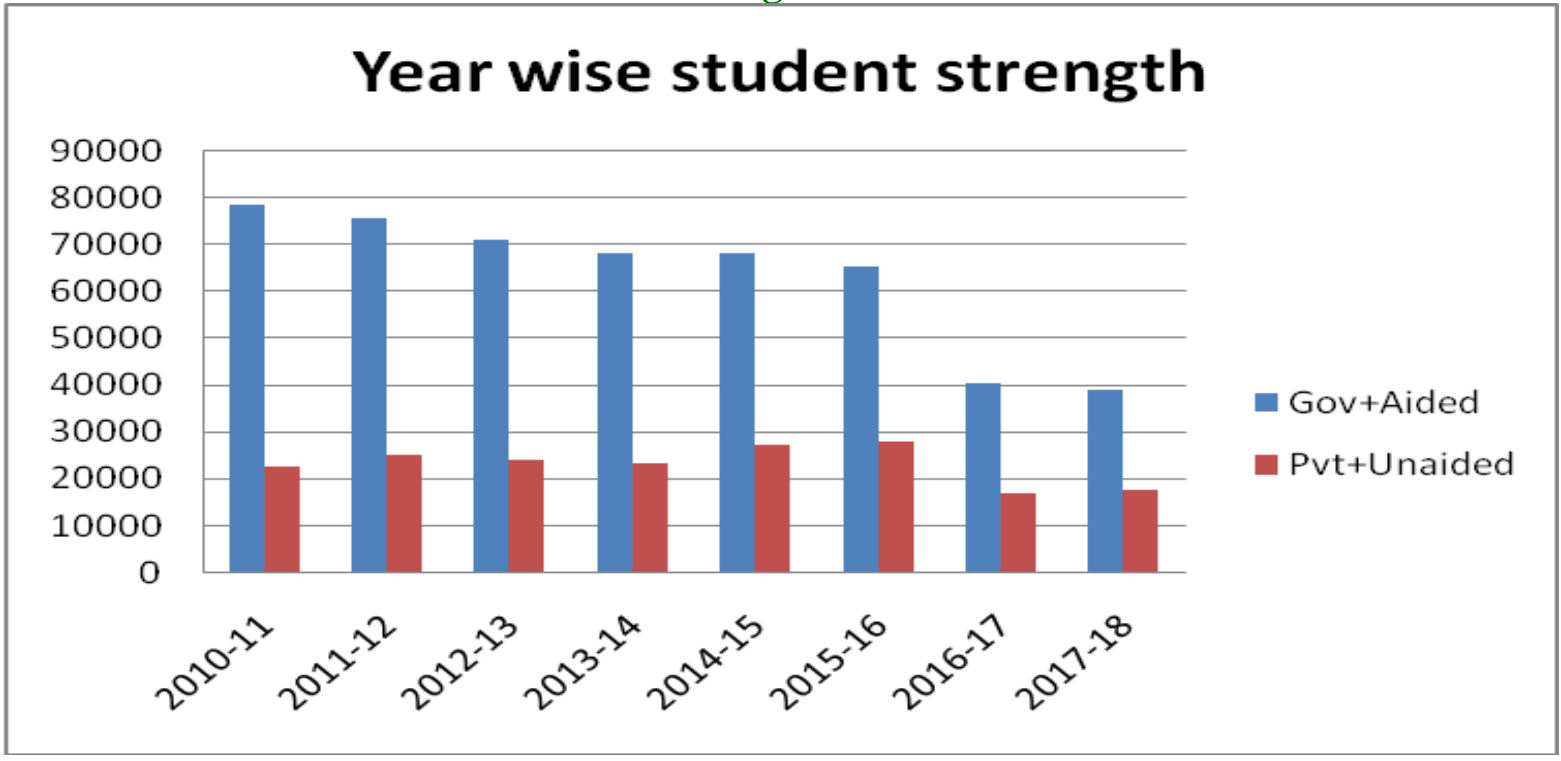

Fig.4b

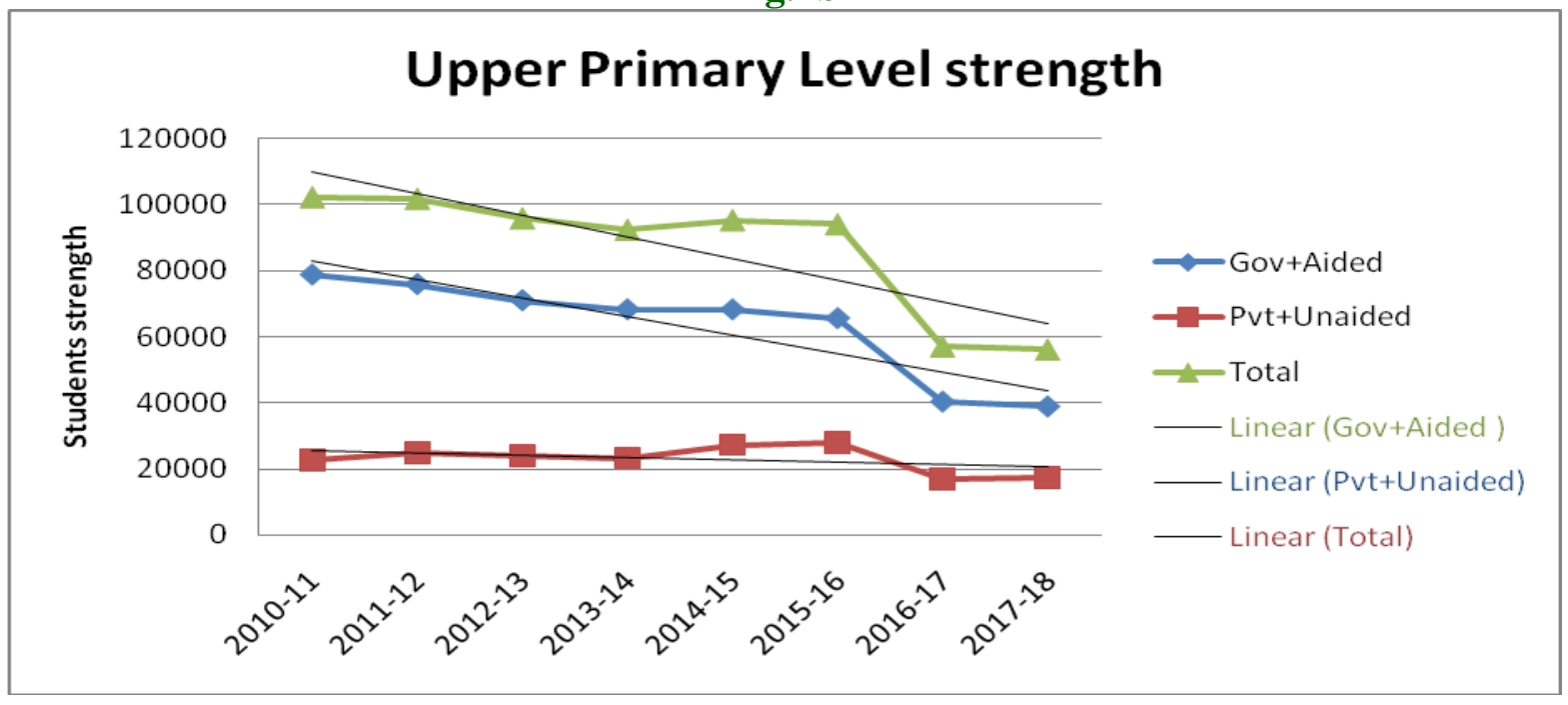


Table.5 Gender wise primary level strength in the Government and Private Schools

\begin{tabular}{|l|l|l|}
\hline \multicolumn{3}{|l|}{ Government School Strength } \\
\hline Year & Boys & Girls \\
\hline $\mathbf{2 0 1 0 - 1 1}$ & 28946 & 28032 \\
\hline $\mathbf{2 0 1 1 - 1 2}$ & 28405 & 29742 \\
\hline $\mathbf{2 0 1 2 - 1 3}$ & 32934 & 34048 \\
\hline $\mathbf{2 0 1 3 - 1 4}$ & 38547 & 39621 \\
\hline $\mathbf{2 0 1 4 - 1 5}$ & 37155 & 37898 \\
\hline $\mathbf{2 0 1 5}-16$ & 38999 & 39747 \\
\hline $\mathbf{2 0 1 6}-17$ & 78090 & 85472 \\
\hline $\mathbf{2 0 1 7}-18$ & 125939 & 84010 \\
\hline
\end{tabular}

Fig.5

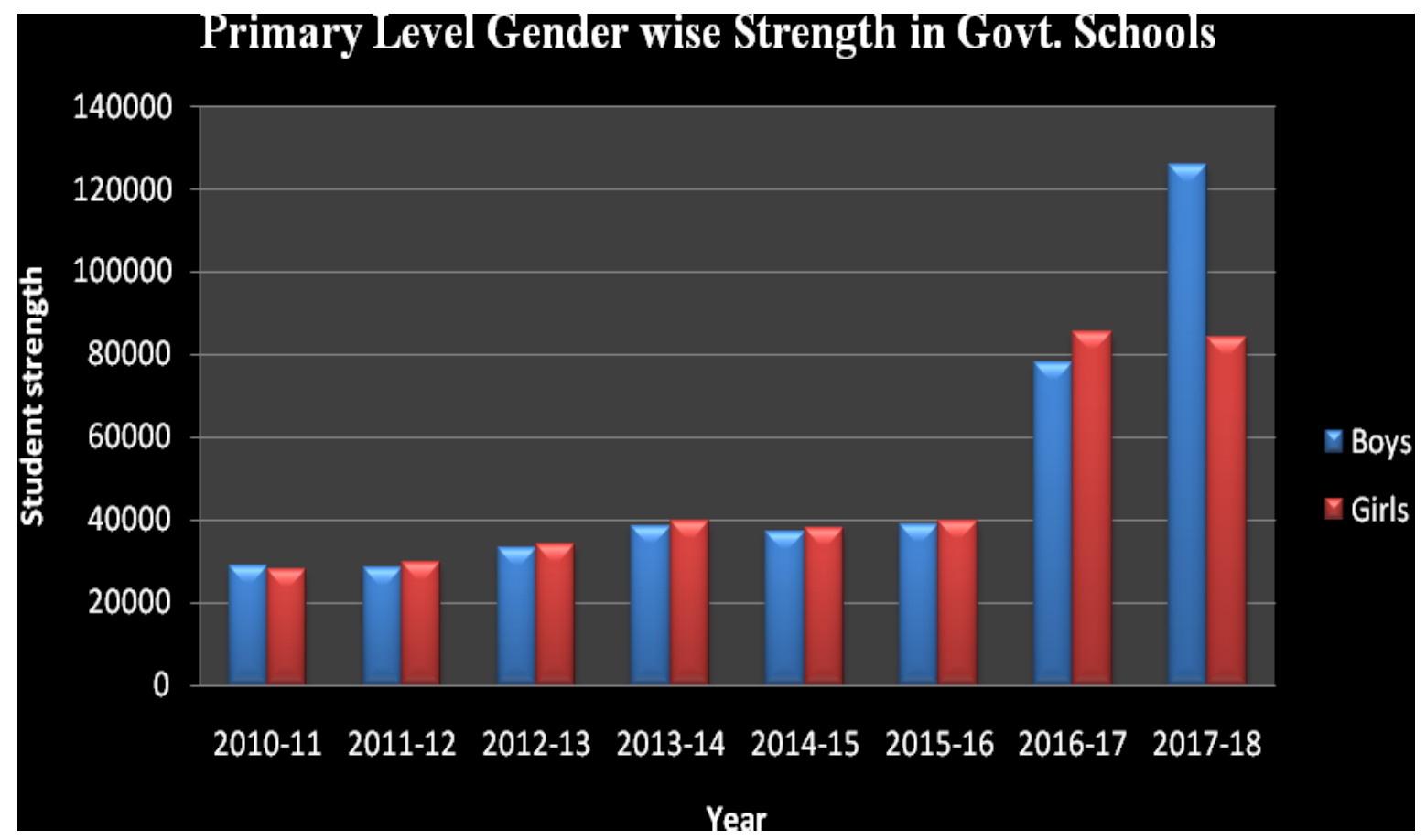

\begin{tabular}{|c|c|c|c|c|c|c|c|c|c|}
\hline \multicolumn{10}{|c|}{ Paired Samples Test } \\
\hline & & \multicolumn{5}{|c|}{ Paired Differences } & \multirow[t]{3}{*}{$\mathrm{t}$} & \multirow[t]{3}{*}{ df } & \multirow{3}{*}{$\begin{array}{l}\text { Sig. (2- } \\
\text { tailed) }\end{array}$} \\
\hline & & \multirow[t]{2}{*}{ Mean } & \multirow[t]{2}{*}{$\begin{array}{l}\text { Std. } \\
\text { Deviation }\end{array}$} & \multirow[t]{2}{*}{$\begin{array}{l}\text { Std. Error } \\
\text { Mean }\end{array}$} & $\begin{array}{l}95 \% \\
\text { Interval } \\
\text { Difference }\end{array}$ & $\begin{array}{l}\text { Confidence } \\
\text { of the }\end{array}$ & & & \\
\hline & & & & & Lower & Upper & & & \\
\hline $\begin{array}{l}\text { Pai } \\
r\end{array}$ & $\begin{array}{l}\text { Boys } \\
\text { Girls }\end{array}$ & $\begin{array}{l}3805 . \\
625\end{array}$ & $\begin{array}{l}15596.71 \\
1\end{array}$ & 5514.270 & - & $\begin{array}{l}16844.80 \\
1\end{array}$ & .690 & 7 & .512 \\
\hline
\end{tabular}


Table.6

\begin{tabular}{|l|l|l|}
\hline \multicolumn{3}{|l|}{ Private Schools Strength } \\
\hline Year & Boys & Girls \\
\hline $\mathbf{2 0 1 0 - 1 1}$ & 38001 & 34805 \\
\hline $\mathbf{2 0 1 1 - 1 2}$ & 39161 & 37226 \\
\hline $\mathbf{2 0 1 2 - 1 3}$ & 42347 & 40787 \\
\hline $\mathbf{2 0 1 3 - 1 4}$ & 50540 & 48924 \\
\hline $\mathbf{2 0 1 4 - 1 5}$ & 50208 & 47453 \\
\hline $\mathbf{2 0 1 5}-16$ & 52360 & 50008 \\
\hline $\mathbf{2 0 1 6}-17$ & 44177 & 30433 \\
\hline $\mathbf{2 0 1 7}-18$ & 57478 & 40604 \\
\hline
\end{tabular}

Fig.6

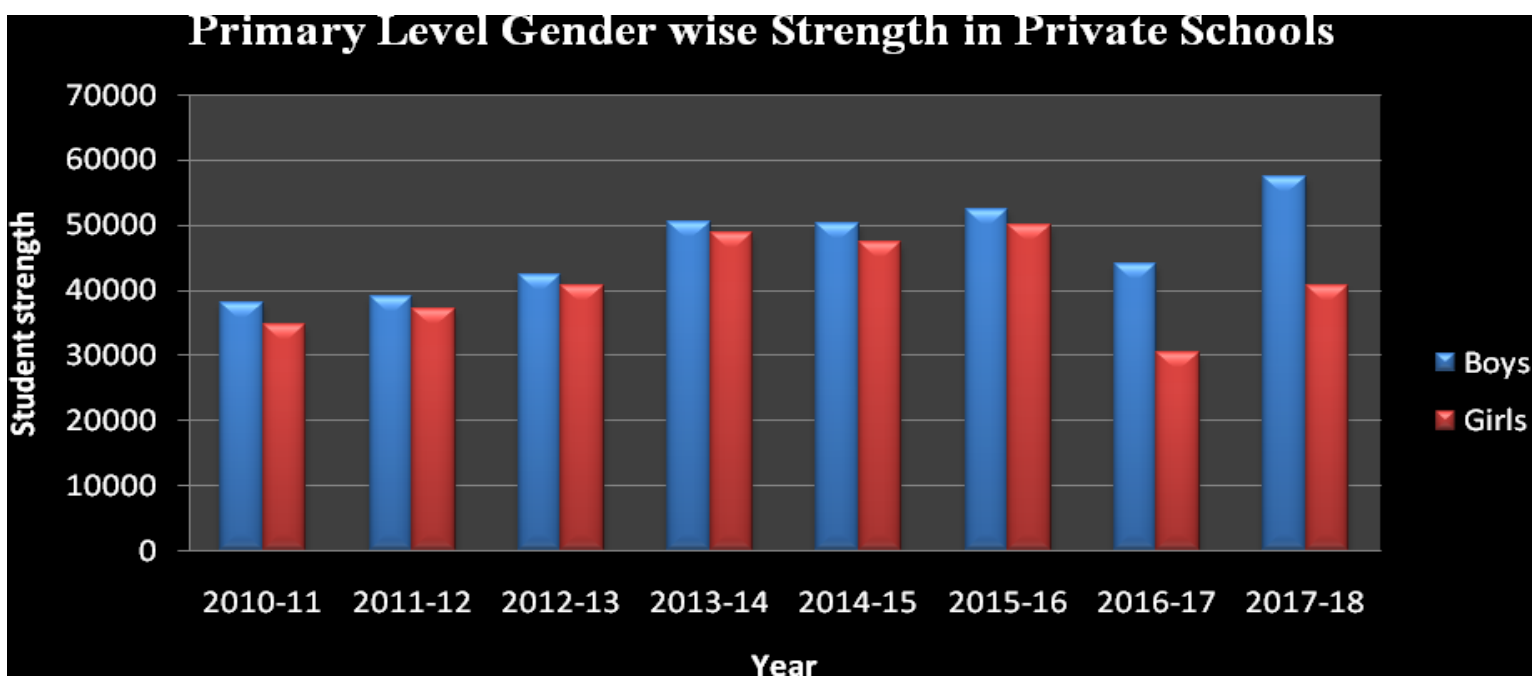

\begin{tabular}{|c|c|c|c|c|c|c|c|c|c|}
\hline \multicolumn{10}{|c|}{ Paired Samples Test } \\
\hline & & \multicolumn{5}{|c|}{ Paired Differences } & \multirow[t]{3}{*}{$\mathrm{t}$} & \multirow[t]{3}{*}{$\mathrm{df}$} & \multirow{3}{*}{$\begin{array}{l}\text { Sig. }(2- \\
\text { tailed) }\end{array}$} \\
\hline & & \multirow[t]{2}{*}{ Mean } & \multirow[t]{2}{*}{$\begin{array}{c}\text { Std. } \\
\text { Deviation }\end{array}$} & \multirow{2}{*}{$\begin{array}{l}\text { Std. } \\
\text { Error } \\
\text { Mean }\end{array}$} & \multicolumn{2}{|c|}{$\begin{array}{c}95 \% \text { Confidence Interval } \\
\text { of the Difference }\end{array}$} & & & \\
\hline & & & & & Lower & Upper & & & \\
\hline Pair 1 & $\begin{array}{l}\text { Boys - } \\
\text { Girls }\end{array}$ & $\begin{array}{c}5504 . \\
000\end{array}$ & 6134.247 & 2168.784 & 375.641 & 10632.359 & 2.538 & 7 & .039 \\
\hline
\end{tabular}

One way analysis of variance test for difference of several means is found to be significant at $5 \%$ level of significance, therefore Null hypothesis $\left(\mathrm{H}_{0}\right)$ is rejected. To observe a specific factor/factors which are significantly varied, it is tested the post hoc test (Tukeys), from the test it is found the three homogeneous subsets of non-significant factors. First subset contains the factors 2013-14, 2015-16, 2016-17, 2017-18 and 2018-19 with P- value 0.865 and second and third subsets contains only single factor 2012-13 and 2014-15 which indicates, these factors means are significantly varying from all the factors with the $\mathrm{P}$ value 1.000 . These factors are non-significant within the subset and significant between the subsets. 
From the means plot it is observed that for 2012-13 and 2014-15 No. of school dropouts is high in the Dharwad district and later on it is significantly decreased to zero. This analysis reveals that there is a significant difference in the year wise number of out of school children (OOSC) and average school dropping students is in control. And also observed the significant difference in the year wise number of school dropouts and average school dropouts are in control.

In conclusion, it is clear from the study that the primary level gender wise student strength in the private schools, from 2010-11 to 2017-18 male strength is slightly more than female strength and female strength in government school is high. This analysis shows that parents are interested to give education to their male child from private schools because of their good opinion about private school. From the figure it is observed that from 2010-11 to till 2016-17 male as well as female student's strength in the private schools is slowly increasing, but for the year 16-17 and 17-18 it is decreased and from the figure- 3 it is observed that male strength is increased in the government school. By observing this, we come to know that govt. Education department drawing new techniques to attract students towards government schools and improving the education quality. From analysis of variance to test equality of means of different years school dropouts, we found significant result that there is a variation in the average dropout from year to year. And average school dropouts are in control (near to zero by 2018).

\section{References}

Aggarwal Y.P. \& Chugh Sunita (2003): Learning Achievement of Slum
Children in Delhi, NIEPA Occasional Paper 34, NIEPA.

Chatterjee, B. (1975): School Dropout among Harijan Children: Causes and Cure Central Institute of Research and Training in Public Cooperation, New Delhi, 1975. September 1998.

Chatterjee, B. (1975): School Dropout among Harijan Children: Causes and Cure Central Institute of Research and Training in Public Cooperation, New Delhi, 1975.

Chatterjee, Madhusudan (1998): The Primary Education among the Poor in the City of Calcutta Paper presented at NUEPA at the workshop on "Indian Mega Cities and Primary Education of the Poor", September 1998.

Chitnis Suma (1982): Dropouts and low pupil achievement among the urban poor in Bombay, Tata Institute of Social Science, Bombay, Mimeo.

Ekstrom. R. B.. Goert z. M. E.• Pollack. J. M.. \& Rock. D. A. (1986). Who drops out of high school and why?. Findings from a national study. Teachers College Record. 87. 356- 373.

Fine. M. (1986). Why urban adolescents drop into and out of public high school. Teachers College Record. 87. 393- 409.

Rao, Mohan, M.J. (2000). "Migration of labour and school dropouts", Social Welfare, 47(6): 26-31

Rao, Rama G and. Mohanty S.K, (2004), "School Enrolment and Dropout: Policies and Achievements", Paper presented in seminar on follow-up of the National Population Policy- 2000: Focus on EAG states, 25-27 Oct. 2004.

Stroup, A. L., \& Robbins, L. N. (1972). Elementary school predictors of high school dropouts among black males. Sociology oj Education, 45, 212-222.

\section{How to cite this article:}

Halawar, S.V. 2019. A Study on School Dropouts and Student Strength of Dharwad District of Karnataka, India. Int.J.Curr.Microbiol.App.Sci. 8(02): 1887-1896.

doi: https://doi.org/10.20546/ijcmas.2019.802.220 